DOI https://doi.org/10.30525/978-9934-26-039-1-91

\title{
ТЕХНОЛОГІЯ «ПЕРЕВЕРНУТОГО НАВЧАННЯ» У ФОРМАТІ ДИСТАНЦЙНОГО ВИКЛАДАННЯ КУРСУ «ЛАТИНСЬКА МОВА ТА МЕДИЧНА ТЕРМІНОЛОГІЯ»
}

\author{
Бондар Н. В. \\ старша викладачка кафедри мовознавства \\ Івано-Франківського начіонального медичного університету
}

м. Івано-Франківськ, Украӥна

Дистанційне навчання є поширеним явищем в університетах різних країн, що забезпечує відкритість та широкодоступність вищої освіти. Особливої актуальності воно набуває сьогодні в умовах світової кризи, що спричинена пандемією Covid-19 і є викликом для суспільства у всіх сферах життя. Форми дистанційного та змішаного навчання стають пріоритетними складовими освітнього процесу в українських вишах. Відбувається перехід від традиційної аудиторної освіти до комп'ютерних інформаційно-комунікаційних технологій, електронних бібліотек та віртуальних навчальних аудиторій. Як зазначають науковці, дистанційне навчання також передбачає, що обидві сторони (викладач та студент) практично постійно знаходяться на зв'язку і спілкуються за допомогою передових технологій [3, с. 194]. Одним із проблемних моментів цього процесу $€$ вибір оптимальних педагогічних методів у відповідності до мети та цілей конкретної дисципліни, які б сприяли досягненню програмних результатів навчання, а також їх адаптація до нового освітнього формату.

Викладання курсу «Латинська мова та медична термінологія» у медичних вишах України покликане забезпечити формування термінологічної компетентності майбутніх фахівців у сфері охорони здоров'я. Предметом вивчення дисципліни $є$ фонетика, граматика й лексика латинської та давньогрецької мов, засвоєння яких необхідне для розуміння міжнародної медичної термінології та ії коректного застосування як засобу комунікації в професійному середовищі. Навчальною програмою дисципліни не передбачені лекції, а тільки практичні заняття та позааудиторна робота студентів. Тобто значний обсяг навчального матеріалу відводиться для самостійного опрацювання студентами, що $\epsilon$ однією 3 характерних тенденцій в сучасній вищій освіті. За таких умов використання формату «перевернутого навчання» в освітньому процесі 
може забезпечити ефективність засвоєння латинської мови як в реальних, так і віртуальних аудиторіях.

Ця форма активного навчання базується на педагогічній моделі «перевернутий клас» (англ. flipped classroom), яка передбачає попереднє самостійне опрацювання теоретичного матеріалу поза аудиторією 3 подальшим закріпленням одержаних знань на практичних заняттях у процесі дискусій, обговорень чи виконання різних практичних завдань. Запропонована американськими викладачами Джонатаном Бергманом та Аароном Самсом, технологія набула популярності й стала об'єктом досліджень як зарубіжних, так і українських вчених $[1 ; 2 ; 4 ; 5]$.

Як зазначає Приходькіна Н., не існує єдиної моделі перевернутого навчання [2, с. 143]. У процесі дистанційного викладання курсу «Латинська мова та медична термінологія» ця технологія реалізується наступним чином. До початку заняття студенти опрацьовують теоретичний матеріал на основі презентацій, паперових чи електронних посібників, веб-сайтів, вивчаючи при цьому нові граматичні конструкції та лексичний мінімум до теми. Натомість практичне заняття забезпечує можливість «негайного практичного застосування отриманих теоретичних знань із наступним обговоренням виниклих питань з викладачем і роз'ясненням ситуації на конкретних прикладах» [3, с. 196]. На занятті студенти відпрацьовують та закріплюють навички перекладу анатомогістологічних термінів 3 латинської мови на українську та навпаки, вчяться тлумачити значення складних клінічних термінів, правильно формулювати діагнози з різних розділів медицини, виписувати рецепти тощо. При дистанційному навчанні таке практичне заняття переноситься у віртуальний простір та відбувається в режимі реального часу на інтернет-платформах Microsoft Teams чи Zoom у форматі онлайн-наради 3 використанням відео- та аудіозв'язку. Варто зауважити, що онлайнплатформа Microsoft Teams пропонує ряд опцій для забезпечення інтерактивної взаємодії учасників освітнього процесу, а саме: віртуальна інтерактивна дошка, панель спільного доступу для завантаження презентацій, віртуальний блокнот для нотаток та співпраці, обмін файлами в чаті тощо.

Впроваджувана технологія передбачає зміщення пріоритетів у навчальному процесі - від пасивного сприйняття інформації студентами до їх активної роботи над засвоєнням матеріалу. Водночас змінюється $\mathrm{i}$ роль викладача, який уже виконує функції тренера чи консультанта на занятті: організовує студентів в робочі групи для виконання певних завдань, відстежує динаміку їхньої успішності та виявляє найбільш поширені помилки студентів у розумінні певних явищ. Викладач 
виступає в ролі фасилітатора, який проектує та супроводжує навчальний процес, координує пізнавальну діяльність студентів [2, с. 142].

Досвід застосування моделі «перевернутого навчання» для вивчення дисципліни «Латинська мова та медична термінологія» дозволяє виділити ii переваги та проблемні моменти. В умовах дистанційної освіти ця технологія стає новим викликом для викладача, оскільки вимагає ретельної підготовки, а саме: необхідність розробки та регулярного оновлення електронних навчально-методичних матеріалів для наповнення веб-контенту (текстові чи відеопрезентації тем, методичні вказівки до занять, електронні навчальні посібники, тестові завдання для онлайн-тренажерів, інтерактивні тренувальні вправи для відпрацювання практичних навичок тощо), а також вдосконалення форм та методів онлайн-контролю 3 метою об'єктивного оцінювання досягнень студентів, забезпечення академічної доброчесності та запобігання академічному плагіату.

Водночас «перевернуте навчання» має ряд переваг для здобувачів освіти, оскільки робить їх активними учасниками навчального процесу, які несуть відповідальність за власні знання. Студенти можуть опрацьовувати новий матеріал до початку заняття у будь-який час та в зручному для них темпі, мають можливість його повторного перегляду чи прослуховування та достатньо часу для його осмислення. Мотивацією до самостійного навчання $є$ різні форми та засоби контролю, як ось: обов'язкове комп'ютерне тестування, вікторини та квести до опрацьованих тем, контрольні завдання, підсумкове оцінювання, а також нестандартні кейси завдань для подальшої групової роботи на занятті, їх колективне обговорення з виправленням допущених помилок та взаємне оцінювання.

Підсумовуючи все вище сказане, доходимо висновку, що впровадження технології «перевернутого навчання» у вищій школі - це своєрідна мотивація до безперервної роботи, навчання та самовдосконалення усіх учасників освітнього процесу.

\section{Література:}

1. Андрейко Л. В. Технологія «перевернутого класу» у викладанні іноземної мови. Емпіричні дослідження для реформування освіти в Україні : збірник матеріалів I Міжнародної наукової конференції Української асоціації дослідників освіти, 11 лютого 2017 р. Київ : Дрогобич: ТзОВ «Трек-ЛТД», 2017. С. 9-11.

2. Приходькіна Н. Використання технології «переверненого навчання» у професійній діяльності викладачів вищої школи. Науковий 
вісник Ужгородського національного університету. Серія : Педагогіка. Соиіальна робота. Ужгород, 2014. Вип. 30. С. 141-144.

3. Самолюк Н., Швець М. Актуальність і проблемність дистанційного навчання. Нова педагогічна думка. Рівне, 2013. № 1.1. С. 193-197.

4. Berrett D. How 'flipping' the classroom can improve the traditional lecture. The Chronicle of Higher Education. Feb. 19, 2012. URL: https:// www.chronicle.com/article/how-flipping-the-classroom-can-improve-thetraditional-lecture/ (дата звернення: 28.01.2021).

5. McLaughlin J.E., Roth M.A., Glatt D.M., Gharkholonarehe N., Davidson C.A., Griffin L., Esserman D.A., Mumper R.J. The flipped classroom: a course redesign to foster learning and engagement in a health professions school. Academic medicine : journal of the Association of American Medical Colleges. 2014. 89 (2). P. 236-243. URL: https://www.semanticscholar.org/paper/The-Flipped-Classroom\%3A-ACourse-Redesign-to-Foster-McLaughlin-Roth/a634dd461038d079a7884139 1a0bdd1cb37c3cc1 (дата звернення: 16.01.2021).

DOI https://doi.org/10.30525/978-9934-26-039-1-92

\title{
ЗАСТОСУВАННЯ УТЕМ-ТЕХНОЛОГІЇ В РАМКАХ КОНЦЕПЦІЇ НОВОЇ УКРАЇНСЬКОЇ ШКОЛИ ДЛЯ УЧНІВ СТАРШИХ КЛАСІВ
}

\author{
Власюк I. В. \\ аспірант кафедри англійської філологї \\ Тернопільського національного педагогічного університету \\ імені Володимира Гнатюка, \\ вчитель англійської та німечької мов \\ Тернопільського навчально-виховного комплексу \\ «Школа-колегіум Патріарха Йосифа Сліпого» \\ Тернопільської міської ради Тернопільської області \\ м. Тернопіль, Украӥна \\ ORCID ID: 0000-0002-6862-697X
}

Постановка проблеми. На сучасному етапі розвитку суспільства 3 великою скорістю відбувається розвиток комп'ютерних технологій та робо-техніки. Такий процес безумовно виступає передумовою формування нової системи освіти. А це відповідно вимагає від держави прийняття нових вимог та формування сприятливого середовища для 138 